\title{
Off-Label and Unlicensed Drug Use in Neonatology: Reality in a Portuguese University Hospital
}

\author{
Uso de Fármacos Off-Label e Não Licenciados em Neonatologia: Realidade de \\ um Hospital Universitário Português
}

Joana SILVA $\rrbracket^{1}$, Filipa FLOR-DE-LIMA ${ }^{1,2}$, Henrique SOARES ${ }^{1,2}$, Hercília GUIMARÃES $^{1,2}$

Acta Med Port 2015 May-Jun;28(3):297-306

ABSTRACT

Introduction: This study aims to characterize the drugs used in a Portuguese Neonatal Intensive Unit Care, assess the rate of off-label or unlicensed drugs use according to the information available in the Summary of Product Characteristics and compare results between preterm and full-term neonates.

Material and Methods: A 6-month period retrospective cross-sectional study was conducted in our Neonatal Intensive Unit Care in 2013. Prescribed drugs data were recorded and compared with the paediatric information contained in drugs Summary of Product Characteristics.

Results: We analyzed 1011 prescriptions of 84 active substances, made in 218 admissions. In $42.9 \%$ of the cases, medicines were used according to Summary of Product Characteristics information; $27.9 \%$ of drugs were approved for neonatal period but used in an off-label manner; off-label drugs for neonates were used in $10.1 \%$, whereas those with undetermined approval state and contraindicated were used $6.0 \%$ and $8.7 \%$ of the cases, respectively. Unlicensed prescriptions accounted for $4.4 \%$ of total. Preterm received a higher rate of drugs used according to Summary of Product Characteristics $(p<0.0001)$, whereas full-term received more off-label drugs for dose/frequency $(p<0.0001)$ and contra-indicated for neonates $(p<0.012)$.

Discussion: Preterm neonates received a higher median number of drugs, since they stayed longer in the unit. The main reason for off-label prescribing was the use of doses/frequencies of administration different from those stated in the Summary of Product Characteristics, suggesting that updating these documents is necessary. Manipulation of medicines is one of the causes for unlicensed drugs use, emphasizing the lack of appropriate formulations for neonatal age.

Conclusion: Progresses have been made to reduce the risks of off-label/unlicensed prescriptions, but competent authorities must continue their efforts to develop safer and more effective drugs for neonatal period.

Keywords: Drug Labeling; Drug Therapy; Infant, Newborn; Intensive Care Units, Neonatal; Off-Label Use; Portugal.

\section{RESUMO}

Introdução: Este estudo pretende caracterizar os medicamentos usados numa Unidade de Cuidados Intensivos Neonatais portuguesa, avaliar a frequência do uso de fármacos off-label ou não licenciados de acordo com a informação disponível no Resumo das Caraterísticas do Medicamento e comparar resultados entre recém-nascidos prematuros e de termo.

Material e Métodos: Um estudo retrospetivo transversal foi conduzido na nossa Unidade de Cuidados Intensivos Neonatais no primeiro semestre de 2013. Os dados das prescrições realizadas foram comparados com a informação pediátrica contida nos Resumos das Caraterísticas do Medicamento.

Resultados: Analisámos 1011 prescrições respeitantes a 84 substâncias ativas, feitas em 218 admissões. Em 42,9\% dos casos, os fármacos foram usados de acordo com a informação do Resumo das Caraterísticas do Medicamento; $27,9 \%$ dos fármacos eram aprovados para o período neonatal mas usados de forma off-label; medicamentos off-label para a idade neonatal foram usados em $10,1 \%$, enquanto aqueles com estado de aprovação indeterminado ou contraindicados foram usados em $6,0 \%$ e $8,7 \%$ dos casos, respetivamente. As prescrições não licenciadas representaram 4,4\% do total. Os recém-nascidos pré-termo receberam uma taxa superior de fármacos usados de acordo com o Resumo das Caraterísticas do Medicamento $(p<0,0001)$, enquanto os de termo receberam mais fármacos off-label para dose/frequência $(p<0,0001)$ e contraindicados para recém-nascidos $(p<0,012)$.

Discussão: Os prematuros receberam um número mediano de fármacos superior, o que se relaciona com o seu internamento mais prolongado. A principal razão para prescrições off-label foi a utilização de doses/frequências de administração diferentes das referidas no Resumo das Caraterísticas do Medicamento, reforçando a necessidade de atualização destes documentos. A manipulação dos medicamentos é uma das causas para o seu uso não licenciado, enfatizando a falta de formulações apropriadas à idade neonatal.

Conclusão: Têm sido feitos progressos para reduzir os riscos destas prescrições off-label/não licenciadas, mas esforços para o desenvolvimento de medicamentos mais seguros e eficazes para este período devem continuar a ser envidados.

Palavras-chave: Farmacoterapia; Portugal; Recém-nascido; Resumo das Características do Medicamento; Unidades de Cuidados Intensivos Neonatais; Uso Off-Label.

\section{INTRODUCTION}

Global policies for prescribing medicines for children have been changed since it was established between the international medical community the need of therapeutical measures adapted to this particular stage of life. ${ }^{1}$

There are two distinct entities when referring to nonlabelled prescriptions: off-label and unlicensed uses. Offlabel relates to medication use beyond the conditions of the registered product as specified in the Summary of Product

\footnotetext{
1. Faculdade de Medicina. Universidade do Porto. Porto. Portugal.

2. Neonatology Division. Paediatric Department. Centro Hospitalar de São João/ Faculdade de Medicina. Universidade do Porto. Porto. Portugal.

$\square$ Autor correspondente: Joana Silva. joanarbsilva0@gmail.com

Recebido: 16 de Fevereiro de 2014 - Aceite: 28 de Abril de 2014| Copyright @ Ordem dos Médicos 2015
} 
Characteristics (SPC) in terms of patient age, indication, dosage, frequency and route of administration. Unlicensed refers to a drug that has not a Marketing Authorization (MA), is not licensed in a country, or does not have an appropriate formulation available in the market. ${ }^{2,3}$

Besides the legality or adequate justification for the use of unlicensed/off-label drugs, it brings ethical dilemmas and can be associated with clinical and safety issues. ${ }^{4-7}$

Many studies have shown that neonates have higher risk of using off-label drugs than the children of other age groups. ${ }^{6,8-11}$ A range from 55 to $80 \%$ in the use of unlicensed or off-label drugs at neonatal settings is referred in literature reviews on this theme; the proportion of patients receiving at least one of these drugs ranges from $80-97 \%$. 5,6,11

Other specificities of neonatology are the added risk of preterm newborns to die or develop serious morbidity throughout life.9,12 For this reason, just like sick full-term newborns are more exposed to the off-label/unlicensed medications, the most premature and low birth weight neonates receive the greatest number of drugs. ${ }^{13-15}$ Moreover, there are also the specific pharmacokinetics and the fast body mass and composition change of newborns, making them particularly susceptible to the risks of developing adverse drug reactions (ADRs) or experiencing errors in adjusting doses or formulations. .,6,9,10 $^{-1}$

In 2010, European Medicines Agency (EMA) published a report that describes existing data on paediatric uses of medicinal products by country. Portuguese data were collected in 22 hospitals referring to inpatients only; offlabel status related information was available in $33 \%$ of the cases, but there was no quantitative measure of the extent of medicines used in paediatric population. ${ }^{16}$

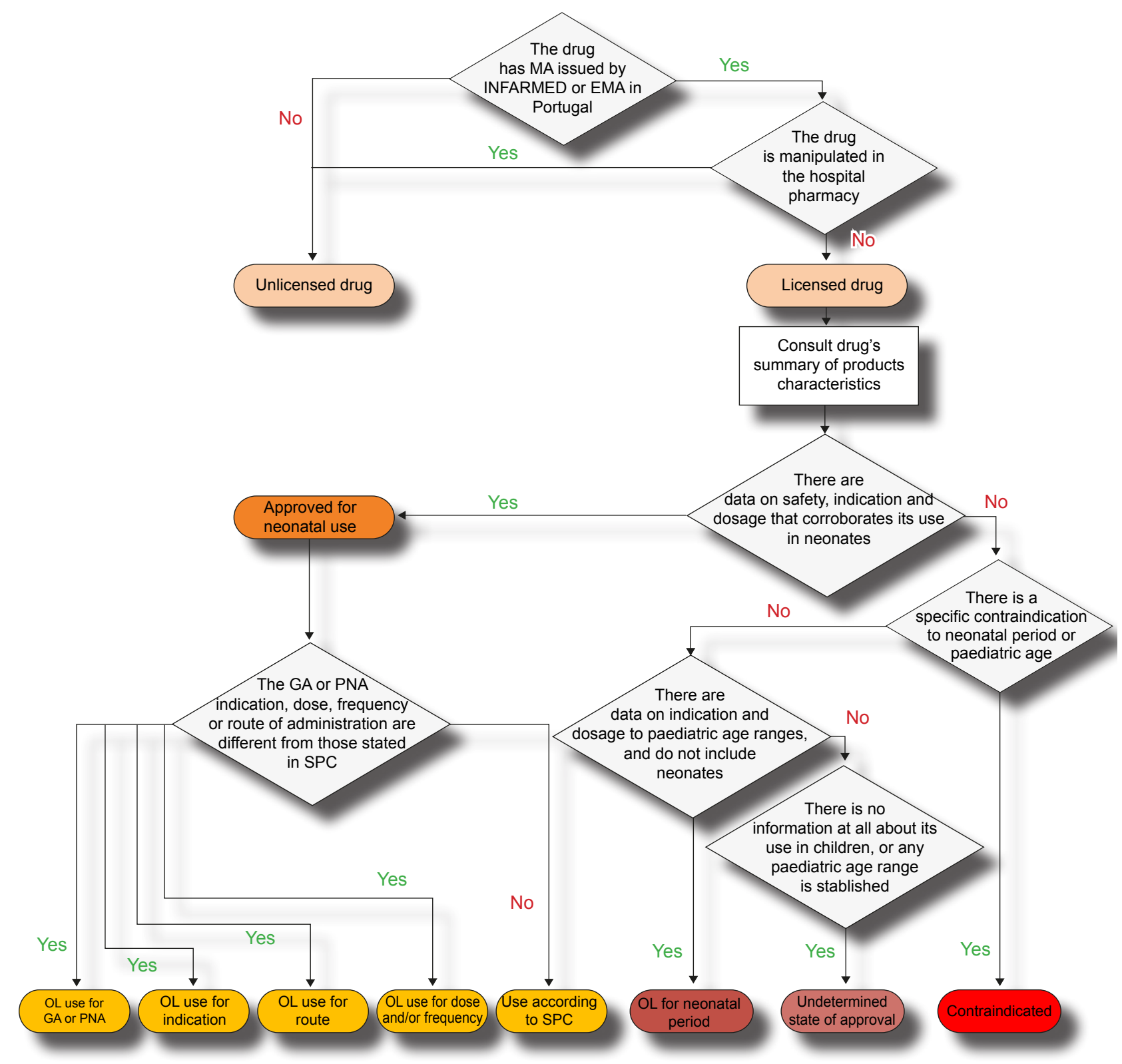

Figure 1 - Decision tree to classify the drugs according to the Marketing Authorization and Summary of Product Characteristics. EMA - European Medicines Agency; GA - Gestational age; MA - Marketing Authorization; OL - Off-label; PNA - Postnatal age; SPC - Summary of Product Characteristics. 
Our study proposes (1) to assess the extent and type of drugs used in our Neonatal Intensive Care Unit (NICU), (2) analyze the frequency of off-label/unlicensed prescriptions according to information available on drugs SPC, and (3) compare results between preterm and full-term neonates.

\section{MATERIAL AND METHODS}

This is a retrospective cross-sectional study, performed at a Portuguese NICU, located at one of the university hospitals that provide tertiary level treatment. This unit of reference has 17 beds, where 445 babies were treated in 2013.

All clinical information and medicines prescribed to neonates (0-27 days of postnatal age, corrected for a gestational age of 40 weeks in case of preterm neonates) admitted in the neonatal unit during a 6-month period (between January $1^{\text {st }}$ and June $30^{\text {th }}, 2013$ ) were recorded in an electronic database, after review the patients' medical records. Recorded information includes demographic data (gender, gestational age, type of delivery, birth weight, Apgar score at first and fifth minutes), clinical information (diagnoses, length of stay, place to where the newborn was discharged) and prescribed drugs data (active substance, codification according to the Anatomical Therapeutic
Chemical (ATC) classification system ${ }^{17}$, indication, dosage, frequency, route of administration and the occurrence of ADRs).

Most prescriptions were based on active substance, so we consulted the SPC from the trademarks provided by hospital pharmacy during this period, available in the database of medicinal products for human use of INFARMED, the regulatory authority of medicines in Portugal. ${ }^{18}$ In case of missing or ambiguous information regarding the use in neonates, other SPCs of the same active substance but different trademark were analyzed and it was considered the one with more extensive data about paediatric use.

Oxygen therapy, intravenous replacement solutions and electrolyte support, flushes for intravenous lines, drugs used during surgeries, enteral and parenteral nutrition, contrast agents, vaccines of Portuguese National Vaccination Programme, blood products (except albumin and immunoglobulins), basic creams, drugs on clinical trials or phototherapy were excluded.

As shown in Fig.1, drugs without MA or manipulated in the hospital pharmacy were classified as unlicensed, while the remaining were considered licensed and subsequently classified into approved, off-label, contraindicated or with

Table 1 - Demographic and clinical characteristics of our patients

\begin{tabular}{|c|c|c|c|c|}
\hline & $\begin{array}{c}\text { Total } \\
\mathrm{n}=\mathbf{2 1 8}\end{array}$ & $\begin{array}{l}\text { Preterm } \\
n=94^{c}\end{array}$ & $\begin{array}{c}\text { Full-term } \\
n=124\end{array}$ & $p$ value \\
\hline \multicolumn{5}{|l|}{ Gender, n (\%) } \\
\hline Male & $121(55.5)$ & $50(53.2)$ & $71(57.3)$ & \multirow{2}{*}{$0.550^{*}$} \\
\hline Female & $97(44.5)$ & $44(46.8)$ & $53(42.7)$ & \\
\hline Gestational age (wk), mean ( \pm SD) & $36.07( \pm 4.0)$ & $32.4( \pm 3.2)$ & $38.9( \pm 1.2)$ & $<0.0001^{\S}$ \\
\hline Birth weight $(g)$, mean $( \pm S D)^{d}$ & $2554( \pm 910.5)$ & $1765( \pm 628.9)$ & $3152( \pm 570.9)$ & $<0.0001^{\S}$ \\
\hline \multicolumn{5}{|l|}{ Delivery, n (\%) } \\
\hline C-section & $120(55.0)$ & $60(63.8)$ & $60(48.4)$ & \multirow{3}{*}{$0.023^{*}$} \\
\hline Vaginal & $71(32.6)$ & $28(29.8)$ & $43(34.7)$ & \\
\hline Forceps or vacuum & $27(12.4)$ & $6(6.4)$ & $21(16.9)$ & \\
\hline \multicolumn{5}{|l|}{ Apgar score $1^{\text {st }} \min , \mathrm{n}(\%)$} \\
\hline $0-7$ & $69(31.8)$ & $30(31.9)$ & $39(31.7)$ & \multirow[t]{2}{*}{$0.974^{*}$} \\
\hline $8-10$ & $148(68.2)$ & $64(68.1)$ & $84(68.3)$ & \\
\hline \multicolumn{5}{|l|}{ Apgar score $5^{\text {th }} \min , \mathrm{n}(\%)$} \\
\hline $0-7$ & $33(15.1)$ & $17(18.1)$ & $16(12.9)$ & \multirow[t]{2}{*}{$0.290^{*}$} \\
\hline $8-10$ & $185(84.9)$ & $77(81.9)$ & $108(87.1)$ & \\
\hline \multicolumn{5}{|l|}{ Place of birth, $n(\%)$} \\
\hline Inborn & $161(73.9)$ & $73(77.7)$ & $88(71.0)$ & \multirow[t]{2}{*}{$0.265^{*}$} \\
\hline Outborn & $57(26.1)$ & $21(22.3)$ & $36(29.0)$ & \\
\hline Number of drugs needed, median (min-max) & $3(0-34)$ & $4(0-34)$ & $2(0-22)$ & $<0.0001^{*}$ \\
\hline Length of stay (days), median (min-max) & $7(1-210)$ & $9(1-210)$ & $6(1-90)$ & $<0.0001^{*}$ \\
\hline \multicolumn{5}{|l|}{ Discharged, n (\%) } \\
\hline Home & $131(60.1)$ & $50(50.3)$ & $81(65.3)$ & \multirow{4}{*}{$<0.0001$} \\
\hline Other hospital & $43(19.7)$ & $32(34)$ & $11(8.9)$ & \\
\hline Other department & $36(16.5)$ & $6(6.4)$ & $30(24.2)$ & \\
\hline Deceased & $8(3.7)$ & $6(6.4)$ & $2(1.6)$ & \\
\hline
\end{tabular}

${ }^{\mathrm{a}}$ Three neonates were admitted twice in the NICU; ${ }^{\mathrm{b}}$ Thirty-three neonates were born from a twin pregnancy; ${ }^{\mathrm{c}}$ Ten neonates $(4.6 \%)$ were extremely preterm $(<28$ weeks), $23(10.1 \%)$ were very preterm (28-31 weeks), 61 (28\%) were late preterm (32-36 weeks); ${ }^{d}$ Thirty-one patients (14.2\%) with very low birth weight ( $\left.\leq 1500 \mathrm{~g}\right) ;{ }^{*} \mathrm{Chi}-\mathrm{square}$ test; ${ }^{\S}$ Independent $\mathrm{t}$ test; ${ }^{*}$ Mann-Whitney $\mathrm{U}$ test. 
undetermined state of approval for neonatal period. We also evaluated if the approved drugs for neonatal use were utilized in an off-label manner regarding to gestational or postnatal age, indication, route of administration, dose and/ or frequency, and these categories may coexist.

Data collection and statistical analysis were performed with IBM SPSS Statistics v. $21^{\circledR}$. Continuous variables were characterized by mean ( \pm standard deviation) and median (minimum-maximum) depending on they had symmetric or asymmetric distribution, respectively, and categorical variables by absolute and relative frequencies. To compare continuous variables we used parametric (independent $t$ test) or non-parametric (Mann-Whitney $U$ test) tests if they had symmetric or asymmetric distribution, respectively. Categorical variables were compared by Chi-squared or Fisher's exact test. A $p$ value less than 0.05 was considered statistically significant.

The protocol was approved by the Ethical Committee and Administrative Council of the institution.

\section{RESULTS}

\section{Population}

A total of 218 admissions were comprised, as shown in
Table 1. From the total patients, $55.5 \%$ were males. Their mean gestational age and birth weight were $36.07 \pm 4.0$ (SD) weeks and $2554 \pm 910.5$ (SD) grams, respectively, with statistically significant differences between preterm and full-term neonates $(p<0.001)$.

Caesarean sections were performed in $55 \%$ of deliveries, with a higher rate in preterm neonates; the vaginal and forceps/vacuum deliveries were more frequent in full-term neonates $(p<0.023)$.

At admission, 165 neonates $(75.7 \%)$ had a medical health condition, whereas $32(14.7 \%)$ had a surgical condition and $21(9.6 \%)$ had a cardiac one.

We categorized all diagnoses in the following categories, in descending order of frequency ( $n$ value; \%): metabolic $(94 ; 27.6 \%)$, cardiovascular $(48 ; 14.1 \%)$, respiratory $(41$; $12.1 \%)$, neurologic/ sense organs $(33 ; 9.7 \%)$, hematologic (32; 9.4\%), digestive (28; 8.2\%), infectious (25; 7.4\%), nephro-urologic (23;6.8\%), and others (16; $4.7 \%)$.

In 54 cases $(24.8 \%)$ oxygen was administered, and 81 neonates $(37.2 \%)$ were in mechanical ventilation. Eighty newborns $(36.7 \%)$ had venous and/or arterial catheters, and 95 newborns (43.6\%) required total parenteral nutrition for a period.

Table 2 - Active substances prescribed to our patients, listed in descending order of frequency of administration

Approved for neonatal period and used according to SPC

Approved for neonatal period but off-label use for gestational age

\author{
Approved for neonatal period but \\ off-label use for indication \\ Approved for neonatal period \\ but off-label use for route of \\ administration \\ Approved for neonatal period \\ but off-label use for dose and/or \\ frequency
}

Off-label for neonatal period

Undetermined approval state for neonates

Contraindicated for neonates

Unlicensed
Cholecalciferol, Caffeine Citrate, Multivitamins, Clotrimazole, Furosemide, Iron(III)Hydroxide Polymaltose, Dopamine, Midazolam, Poractant Alfa, Vancomycin, Cefotaxime, Alprostadil, Paracetamol, Epoetin Beta, Ibuprofen, Phytomenadione, Iron(III)-Hydroxide Sucrose, Phenobarbital, Palivizumab, Atropine, Nystatin, Teicoplanin, Meropenem, Milrinone, Flucloxacillin, Naloxone, Alfacalcidol, Digoxin, Erythromycin, Hepatitis B Immunoglobulin, Levocarnitine, Nitric Oxide

Paracetamol, Amikacin, Fluconazole

Midazolam

Calcium Polystyrene Sulphonate

Gentamicin, Ampicillin, Paracetamol, Amikacin, Vancomycin, Metronidazole, Phenobarbital, Cefotaxime, Teicoplanin, Milrinone, Fluconazole

Domperidone, Ranitidine, Sodium Bicarbonate, Cefazolin, Fentanyl, Salbutamol, Budesonide, Human Immunoglobulin G, Aciclovir, Ipratropium Bromide, Levetiracetam, Adenosine, Amphotericin B, Cefaclor, Flumazenil, Isoprenaline, Levosimendan, Lysine Acetylsalicylate, Ofloxacin, Phenylephrine

Dexamethasone, Epinephrine , Tropicamide, Dobutamine, Gentamicin (ophtalmic), Fusidic Acid, Human Albumin, Hydrocortisone, Norepinephrine, Oxytetracycline

Morphine, Chloramphenicol, Phenylephrine (ophtalmic), Miconazole, Rifamycin

Trimethoprim, Chloral Hydrate, Propranolol, Spironolactone, Acetylsalicylic Acid, Ursodeoxycholic Acid, Calcium Carbonate, Flecainide, Hydrochlorothiazide, Captopril, Folic Acid, Omeprazole 
Median length of stay was 9 days to preterm and 6 days to full-term neonates $(p<0.001)$. At the time of discharge, $96.3 \%$ of these were alive; full-term neonates were more discharged to home and less discharged to other hospitals than preterm neonates $(p<0.001)$.

\section{Drug prescriptions}

A total of 1011 prescriptions were made, concerning to 84 different active substances (Table 2). The median number of drugs needed to each newborn was 3 ( $p<$ $0.001)$. The maximum number of medicines used in preterm and full-term population was 34 and 22 per patient, respectively (Table 1 ); $69.7 \%$ of patients received at least one off-label/unlicensed drug $(72.3 \%$ in preterm and $67.7 \%$ in full-term neonates). In 30 cases (13.8\%), all of them with a gestational age $\geq 35$ weeks, the patients did not receive any drug.

As shown in Fig. 2, most used drugs were anti-infectives for systemic use $(31.9 \%)$, followed by those which act upon the nervous system $(18.4 \%)$, alimentary tract $(14.7 \%)$,

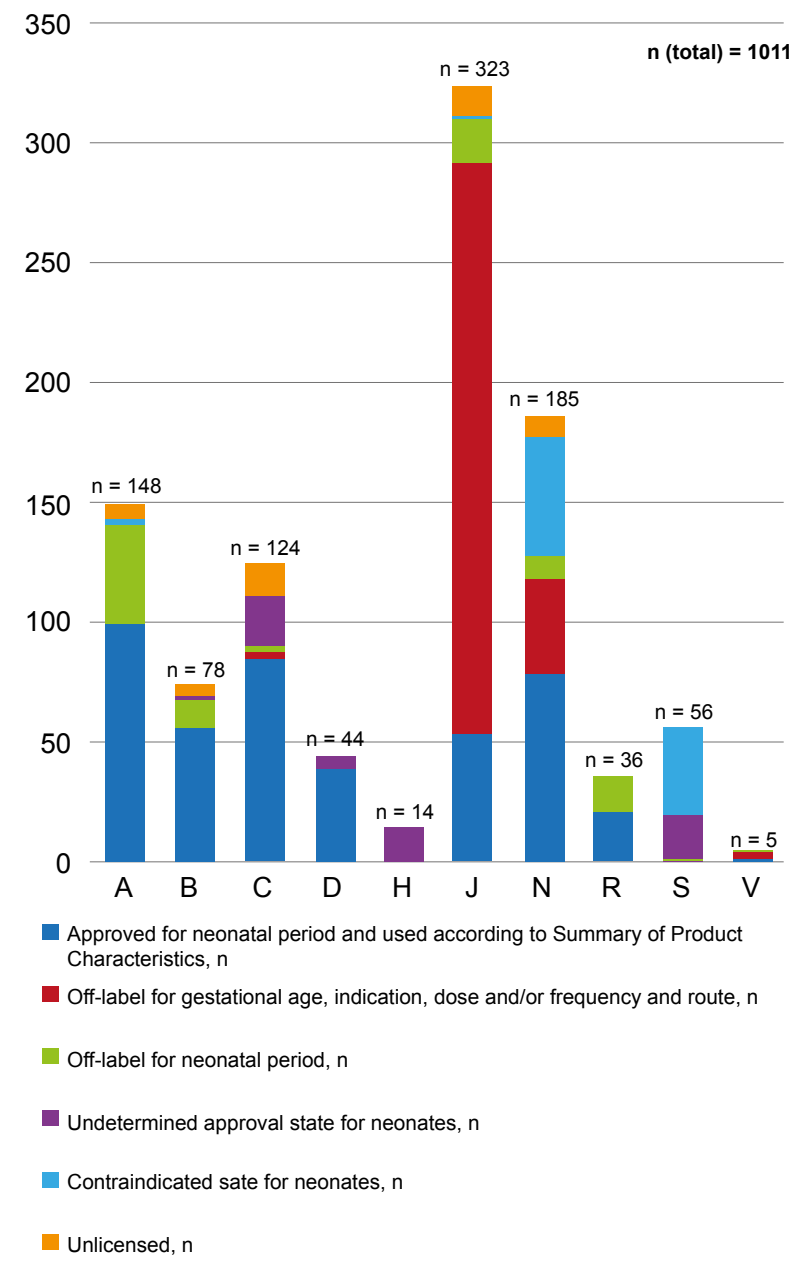

Figure 2 - The distribution of drugs administered according to the Anatomical Therapeutic Chemical Classification system ( $n=1011$ prescriptions).

A - Alimentary tract and metabolism; B - Blood and blood forming organs; C - Cardiovascular system; D - Dermatological; H - Systemic hormonal preparations; J - Anti-infective for systemic use; N - Nervous system; R - Respiratory system; S - Sensory organs; VVarious. cardiovascular system (12.3\%), and blood forming organs (7.3\%).

The top 10 administered drugs were gentamicin $(n=$ 104), ampicillin ( $n=94)$, cholecalciferol $(n=60)$, morphine ( $n=49)$, paracetamol $(n=43)$, caffeine citrate $(n=40)$, multivitamins $(n=38)$, clotrimazole $(n=35)$ furosemide $(n=$ $32)$, and iron hydroxide polymaltose $(n=30)$.

The percentage of prescriptions of approved drugs for neonatal period was $70.8 \%$, but only $42.9 \%$ of total were used according to SPCs information ( $p<0.0001)$. In $25.7 \%$ of the cases, the drugs were off-label for dose and/ or frequency $(p<0.0001)$ and $1.4 \%$ were simultaneously off-label for gestational age and dose $(p<0.001)$. The remaining prescriptions $(29.2 \%)$ were non-labelled for this age group: $10.1 \%$ were off-label, $8.7 \%$ were considered contraindicated $(p<0.012), 6 \%$ had undetermined state of approval for neonates, and $4.4 \%$ were unlicensed, as shown in Table 3.

The intravenous route was the most applied, in $61.4 \%$ of the cases $(p<0.0001)$. As can been seen in Table 4 , it was followed by oral route in $21.5 \%$ of prescriptions $(p<0.003)$.

\section{DISCUSSION \\ Prescription in neonatal setting}

To our knowledge, this is the first study evaluating offlabel and unlicensed drug prescriptions in a Portuguese NICU. Our study population represents the typical one of a specialised NICU, consisting of a high rate of patients transferred from other hospitals $(26.1 \%)$ and a median length of stay of seven days. In other NICU's, median values reported were superior (11-15 days). ${ }^{12,13,19}$ The transfers to other hospitals done in $19.7 \%$ of the cases, mainly in preterm neonates, could explain these differences. As we can verify in Table 1, preterm neonates had a longer stay (median of 9 days), which is consistent with high rates of medical complications needing prolonged NICU stays. ${ }^{15}$ Each newborn was exposed to a median of three different drugs. Two recent studies performed in NICUs with similar prevalence of off-label/unlicensed drugs use reported an equal median, ${ }^{20,21}$ whereas others refer median from 4 to 8 drugs per patient. ${ }^{12,13,19}$ With regard to the higher number of drugs necessary in preterm neonates (median $=4$ ), it confirms the current knowledge that younger, lighter and most vulnerable newborns receive more drugs than the more matures. ${ }^{13-15}$

Beyond the classical division into off-label and unlicensed drugs, we chose to add 'undetermined state approval' and 'contraindicated' categories, in order to be more precise in data analysis. However, typically they are included in off-label category by other authors. ${ }^{12,14}$

In order to compare our results with international reality, we will consider the designation off-label in a broader sense, as concerning to a use not recorded in the SPC for a drug approved in Portugal. Thereby, the sum of drugs used in off-label manner to neonatal period, gestational age, indication, dose/frequency and route of administration, together with those with undetermined approval state 
Table 3 - Approved drugs for neonatal period $(n=716)$ and non-approved approved drugs for neonatal period $(n=295)$

\begin{tabular}{|c|c|c|c|c|}
\hline & $\begin{array}{c}\text { Total } \\
(\mathrm{n}=1011)\end{array}$ & $\begin{array}{l}\text { Pre-term } \\
(n=596)\end{array}$ & $\begin{array}{l}\text { Full-Term } \\
(n=415)\end{array}$ & $p$ value \\
\hline Approved for neonatal period, $\mathrm{n}(\%)$ & $\begin{array}{c}716 \\
(70.8)\end{array}$ & $\begin{array}{c}433 \\
(72.6)\end{array}$ & $\begin{array}{c}283 \\
(68.2)\end{array}$ & $0.125^{\S}$ \\
\hline Drugs used according to SPC, $\mathrm{n}(\%)$ & $\begin{array}{c}434 \\
(42.9)\end{array}$ & $\begin{array}{c}294 \\
(49.3)\end{array}$ & $\begin{array}{c}140 \\
(33.7)\end{array}$ & $<0.0001^{*}$ \\
\hline Off-label for GA, n (\%) & $\begin{array}{c}2 \\
(0.2)\end{array}$ & $\begin{array}{c}2 \\
(0.3)\end{array}$ & $\begin{array}{c}0 \\
(0.0)\end{array}$ & $0.521^{\S}$ \\
\hline Off-label for indication, $\mathrm{n}(\%)$ & $\begin{array}{c}4 \\
(0.4)\end{array}$ & $\begin{array}{c}1 \\
(0.2)\end{array}$ & $\begin{array}{c}3 \\
(0.7)\end{array}$ & $0.306^{\S}$ \\
\hline Off-label for route of administration, $\mathrm{n}(\%)$ & $\begin{array}{c}2 \\
(0.2)\end{array}$ & $\begin{array}{c}1 \\
(0.2)\end{array}$ & $\begin{array}{c}1 \\
(0.3)\end{array}$ & $0.762^{\S}$ \\
\hline Off-label for dose and/or frequency, $\mathrm{n}(\%)$ & $\begin{array}{c}260 \\
(25.7)\end{array}$ & $\begin{array}{c}121 \\
(20.3)\end{array}$ & $\begin{array}{c}139 \\
(33.5)\end{array}$ & $<0.0001^{*}$ \\
\hline Off-label for GA and for dose, n (\%) & $\begin{array}{c}14 \\
(1.4)\end{array}$ & $\begin{array}{c}14 \\
(2.3)\end{array}$ & $\begin{array}{c}0 \\
(0.0)\end{array}$ & $0.001^{\S}$ \\
\hline Non-approved for neonatal period, n (\%) & $\begin{array}{c}295 \\
(29.2)\end{array}$ & $\begin{array}{c}163 \\
(27.4)\end{array}$ & $\begin{array}{c}132 \\
(31.8)\end{array}$ & $0.125^{\S}$ \\
\hline Off-label for neonatal period, $\mathrm{n}(\%)$ & $\begin{array}{c}102 \\
(10.1)\end{array}$ & $\begin{array}{c}63 \\
(10.6)\end{array}$ & $\begin{array}{c}39 \\
(9.4)\end{array}$ & $0.542^{\S}$ \\
\hline Undetermined approval state for neonates, n (\%) & $\begin{array}{c}61 \\
(6.0)\end{array}$ & $\begin{array}{c}37 \\
(6.2)\end{array}$ & $\begin{array}{c}24 \\
(5.8)\end{array}$ & $0.780^{\S}$ \\
\hline Contra-indicated for neonates, $\mathrm{n}(\%)$ & $\begin{array}{c}88 \\
(8.7)\end{array}$ & $\begin{array}{c}41 \\
(6.9)\end{array}$ & $\begin{array}{c}47 \\
(11.3)\end{array}$ & $0.012^{\S}$ \\
\hline Unlicensed, n (\%) & $\begin{array}{c}44 \\
(4.4)\end{array}$ & $\begin{array}{c}22 \\
(3.7)\end{array}$ & $\begin{array}{c}22 \\
(5.3)\end{array}$ & $0.217^{\S}$ \\
\hline
\end{tabular}

and contraindicated, results in a total of $52.7 \%$ off-label prescriptions $(47.0 \%$ in preterm and $60.9 \%$ in full-term neonates), as shown in Table 3. This frequency is similar to those described in recent studies $(46.5 \%-65 \%)$, ${ }^{21-24}$ but is superior to some researches that report rates of $15.5 \%{ }^{7}$, $27.7 \%{ }^{14}$ and $29.5 \%{ }^{19}$

In studies where off-label/unlicensed prescriptions are presented together, prevalence rates range from $34 \%$ to $69 \%{ }^{10,12,14,19,20,23-25}$ Comparing to our results, if we add the use of unlicensed to off-label drugs, a rate of $57.1 \%$ offlabel/unlicensed prescriptions is obtained, according to SPCs information.

The wide range of results detected between our study and others mentioned above may be due to differences in the definitions of off-label use, licensing practices/policies in different countries, and the type of hospital where the study is performed. ${ }^{13}$ The reviews that show rates of $55-80 \%$ of off-label/unlicensed drugs, describe studies conducted years ago; meanwhile, drug labelling for some drugs have been amended. 6,11

We identified 84 active substances used, all listed in
Table 2 according to their application and SPCs information. The number of products identified varies greatly between the studies, depending on the period and number of units included; it ranges from 24 drugs in a 4-month study in a single unit to 93 in a 24-hours evaluation in 17 NICUs. ${ }^{19-21,24}$

Like in other studies, anti-infectives for systemic use and drugs for central nervous system were the most prescribed (Fig. 2). ${ }^{12}$

\section{Approved drugs in neonatal period}

Limiting the discussion to drugs approved for neonatal age, a statistically significant difference in the use of drugs according to the SPC was verified, with almost half of drugs utilized in preterm neonates following SPCs advices (Table 3). In fact, some drugs employed in prematurity are so specific that studies were performed to define doses and get authorization; some of them, like ibuprofen for patent ductus arteriosus and caffeine citrate for apnoea of prematurity, are even orphan drugs.

In several studies, the main reason for off-label classification was the lack of paediatric information, 
Table 4 - Drugs by route of administration

\begin{tabular}{|c|c|c|c|c|}
\hline & $\begin{array}{c}\text { Total of } \\
\text { prescriptions } \\
n=1011\end{array}$ & $\begin{array}{c}\text { Preterms } \\
n=596\end{array}$ & $\begin{array}{c}\text { Full-terms } \\
n=415\end{array}$ & $p$ value \\
\hline Intravenous, n (\%) & $\begin{array}{c}622 \\
(61.4)\end{array}$ & $\begin{array}{c}329 \\
(55.2)\end{array}$ & $\begin{array}{c}293 \\
(70.6)\end{array}$ & $<0.0001^{*}$ \\
\hline Oral, n (\%) & $\begin{array}{c}217 \\
(21.5)\end{array}$ & $\begin{array}{c}147 \\
(24.7)\end{array}$ & $\begin{array}{c}70 \\
(16.9)\end{array}$ & $0.003^{*}$ \\
\hline Ophtalmic, n (\%) & $\begin{array}{c}56 \\
(5.5)\end{array}$ & $\begin{array}{c}38 \\
(6.4)\end{array}$ & $\begin{array}{c}18 \\
(4.3)\end{array}$ & $0.163^{*}$ \\
\hline Transdermal, n (\%) & $\begin{array}{c}40 \\
(4.0)\end{array}$ & $\begin{array}{c}25 \\
(4.2)\end{array}$ & $\begin{array}{c}15 \\
(3.7)\end{array}$ & $0.642^{*}$ \\
\hline Endotracheal, n (\%) & $\begin{array}{c}25 \\
(2.5)\end{array}$ & $\begin{array}{c}22 \\
(3.7)\end{array}$ & $\begin{array}{c}3 \\
(0.7)\end{array}$ & $0.003^{\S}$ \\
\hline Inhalation, n (\%) & $\begin{array}{c}11 \\
(1.1)\end{array}$ & $\begin{array}{c}8 \\
(1.3)\end{array}$ & $\begin{array}{c}3 \\
(0.7)\end{array}$ & $0.382^{\S}$ \\
\hline Subcutaneous, n (\%) & $\begin{array}{c}10 \\
(1.0)\end{array}$ & $\begin{array}{c}10 \\
(1.7)\end{array}$ & $\begin{array}{c}0 \\
(0.0)\end{array}$ & $0.007^{\S}$ \\
\hline Intramuscular, n (\%) & $\begin{array}{c}6 \\
(0.6)\end{array}$ & $\begin{array}{c}4 \\
(0.7)\end{array}$ & $\begin{array}{c}2 \\
(0.5)\end{array}$ & $0.700^{\S}$ \\
\hline Buccal, n (\%) & $\begin{array}{c}4 \\
(0.4)\end{array}$ & $\begin{array}{c}1 \\
(0.2)\end{array}$ & $\begin{array}{c}3 \\
(0.7)\end{array}$ & $0.311^{\S}$ \\
\hline Instillation ${ }^{\mathrm{a}}$, n (\%) & $\begin{array}{c}1 \\
(0.1)\end{array}$ & $\begin{array}{c}1 \\
(0.2)\end{array}$ & $\begin{array}{c}0 \\
(0.0)\end{array}$ & $0.404^{\S}$ \\
\hline Nasal, n (\%) & $\begin{array}{c}1 \\
(0.1)\end{array}$ & $\begin{array}{c}0 \\
(0.0)\end{array}$ & $\begin{array}{c}1 \\
(0.2)\end{array}$ & $0.410^{\S}$ \\
\hline Two or more, $\mathrm{n}(\%)$ & $\begin{array}{c}18 \\
(1.8)\end{array}$ & $\begin{array}{c}11 \\
(1.7)\end{array}$ & $\begin{array}{c}7 \\
(1.7)\end{array}$ & $0.815^{*}$ \\
\hline
\end{tabular}

Instillation in a nephrostomy; ${ }^{*}$ Chi-square test; ${ }^{\S}$ Fisher's exact test.

especially for neonates. ${ }^{10,20}$ In others, off-label use was assigned to different doses and dosing frequencies from those recommended in product licenses. ${ }^{3,11,23}$ The latter is the main reason that led us to classify an approved drug as off-label too, which occurred in $33.5 \%$ of the cases in fullterm and $20.3 \%$ in preterm neonates $(p<0.001)$.

Most drugs used in a dose and/or frequency different from those stated in SPC are anti-infectives for systemic use. Ampicillin and gentamicin were the most prescribed antibiotics, once the empirical therapy for newborns should be based on a combination of ampicillin and an aminoglycoside. ${ }^{26}$ Their labels contain information concerning to variable doses according to weight and postnatal age, respectively, but do not consider the variations in pharmacokinetics that occurs with the gestational age at birth time. Gentamicin was also used in a single daily dosing, although SPC solely describes divided doses. The medical prescription in our ward is supported several times by paediatric handbooks and scientific papers, reason why we consulted LexiComp's Pediatric \& Neonatal Dosage Handbook. This publication takes into account the gestational age and weight, so these anti-infective prescriptions would not be off-label if we considered only the book. ${ }^{27}$ A survey on off-label antibiotic use performed in three European countries describes an unregistered dose use in a range of $37.8 \%$ to $51.7 \%$ of prescriptions in NICU, so our findings are in line with European reality. ${ }^{26}$

There were also statistically significant differences in the use of off-label drugs for gestational age and dose, since it was in preterm infants that these drugs were administered in these conditions. To exemplify, intravenous paracetamol SPC refers that 'data on safety and efficacy are not available for preterm newborns', although the oral paracetamol SPC does not mention the absence of this data and displays dosage for infants weighing less than $4000 \mathrm{~g}$, regardless of gestational age.

\section{Off-label prescribing for neonatal period}

In $10.1 \%$ of the prescriptions, SPCs of corresponding drugs establish a minimum age limit from which their use is approved: budesonide can be used in children over 2 years of age, while adenosine efficacy and safety in children aged between 0 and 18 years has not been established (Table 3). Not all drugs classified in Table 2 as off-label for 
neonatal period are due to age group. For example, sodium bicarbonate was prescribed in a concentration of $8.4 \%$, but its SPC recommends the administration of a concentration of $4.2 \%$ in children younger than 2 years.

Ranitidine and domperidone, belonging to the third ATC category most used in our population, are useful examples to demonstrate other findings. According to SPC, the safety of using ranitine in children under 12 years is not fully elucidated. In an attempt to clarify the authorised age group for this drug, we consulted the assessment of needs of gastroenterological drugs for paediatric age published in 2006, and no age limit was identified in France, but in Germany it is approved for children older than 6 years. ${ }^{28}$ We consulted LexiComp's Handbook too, noticing that it has information on ranitidine neonatal dosing. ${ }^{27}$ The recommended dosage in domperidone SPC comprises only children over 2 years; however, in the already referred EMA's document, domperidone is considered to be already covered and that there is no need for further paediatric data; ${ }^{28}$ in LexiComp's handbook, it is not even mentioned. ${ }^{27}$ Thus, we can conclude that the information conveyed by different authorities is unequal and requires an increased effort in decision-making by paediatricians.

During our approach, other SPCs of the same active substances were read and we found lack of updated information about neonatology use in some of them. For example, SPC of ampicillin trademark supplied by hospital pharmacy is silent on neonatal use or posology, but other trademark SPC exposes information about it. This would result in a possible categorization of off label drug to neonatal period, only because the label is not updated. As mentioned in other works, including one performed in Portugal, many of the drugs used in this period are in the market for several years. Nevertheless, the SPCs were not updated, although there is a long clinical experience in their use. ${ }^{4,29}$

We also verified that in $6.0 \%$ of prescriptions, the SPCs consulted have no specific information on the use of the drug in paediatric population, so prescriptions were classified as 'undetermined state of approval' (Table 3). They deliver ambiguous information, like 'should be administered with caution in children' stated in dexamethasone SPC. However, it is a lower percentage when compared with the $22.7 \%$ of drugs referred in an Italian study as containing no information for paediatric use. ${ }^{24}$

\section{Contraindicated drugs}

As presented in Table 3, $8.7 \%$ of all prescriptions in the NICU were contraindicated drugs administered in a statistically significant higher proportion in preterm neonates $(4.7 \%)$. This percentage is much higher than observed in other studies; in one of them, authors reported a rate of $0.3 \%$ of contraindicated drugs use in neonates. ${ }^{30}$

Morphine was the most frequently contraindicated drug used, once it's SPC states dosage for children over 1 year and contraindication for newborns, as they present increased sensitivity to opioids and consequently greater depression of respiratory center. Indeed, it was been identified by EMA as authorized to infants over 6 months, but it is still necessary data on pharmacokinetics, safety and efficacy in younger children. ${ }^{28}$ However, there are recommended doses for this age group and its management is done in intensive care, minimizing the risks of respiratory depression. ${ }^{27}$

\section{Unlicensed prescribing}

In $4.4 \%$ of the prescriptions, drugs were classified as unlicensed, for three main reasons: some active substances, like trimethoprim and hydrochlorothiazide, are currently marketed only in combination with other active substances; some drugs are no longer available in the market, like chloral hydrate; and, at last, drugs like propranolol and spironolactone are not marketed in formulations suitable for neonatal age (Table 3). The oral formulations are available only in tablets or capsules, so their manipulation in the hospital pharmacy is required in order to be possible to babies swallow the medicine..$^{29}$ Of unlicensed drugs shown in Table 4, almost all are mentioned in the list of reimbursed manipulated medicines, published in Portuguese Official Journal in 2010 (except acetylsalicylic acid and calcium carbonate), demonstrating that knowledge of the existence of gaps in the medicines prepared industrially is not recent. ${ }^{31}$ Such manipulated formulations have poor information regarding bioavailability and stability, so the only way to overcome a potential unnecessary risk of their administration in neonates would be the investment of pharmaceutical companies in new oral formulations in spite of the small paediatric market. 2,20,29,32 However, appropriate formulations do not obviate the need for more studies on safety and efficacy directed to these active substances, since available SPCs of these drugs do not contain satisfactory information for paediatric age. The absence of SPCs, as in the case of chloral hydrate, would leave doctors without documentary support for its therapeutic choice, if there were no reference books. This failure could justify the findings of a recent study that related medication errors and medicines license status, in which unlicensed drugs use appears to be associated with medication errors in neonates and children. ${ }^{22,33}$

In Portugal, like in other countries, the use of a drug outside of the approved indications is the responsibility of the prescribing physician, ${ }^{20}$ and INFARMED declared that it is responsibility of the pharmacy, therapeutics and/or ethics committees of each institution to decide on the correctness of therapy prescribed to patients. ${ }^{34}$ In order to avoid legal problems, the risks and benefits of the drug should be explained to the carer, regardless the license status. However, the informed, enlightened and free consent should be given in writing in the particular situation of using drugs off-label. ${ }^{35}$

\section{Route of administration}

The evaluation of the administration routes showed significant differences between the two population groups (Table 4). Intravenous route was the most utilized $(61.4 \%$ of total), being even more apparent this trend in full term neonates who received $70.6 \%$ of drugs by this route. Oral 
route was used in $21.5 \%$ of the cases, mainly in preterm neonates $(p<0.003)$. This is an unexpected result, since their immaturity when compared with the full-term would lead to suppose that oral route was more used in latter. In other study the results are dissimilar, with enteral route being the most used ( $49 \%$ of cases), followed by parenteral one $(46 \%) .{ }^{13}$

The remaining statistically differences were verified in drugs administered by endotracheal and subcutaneous routes, used mainly in preterm neonates due to the drugs characteristics. They used poractant alpha, a surfactant to endotracheobronchial instillation utilized in the treatment or prophylaxis of respiratory distress syndrome in newborns; likewise, epoetin beta, a drug approved for the prevention of anaemia of prematurity, was the only one administered subcutaneously.

\section{Adverse drug reactions}

In contrast with one of the first studies that evaluated ADRs in neonates, which found a rate of $6 \%$ of ADRs in a population similar to ours (where was used off-label and/ or unlicensed in $55 \%$ of the cases), ${ }^{6}$ no ADRs to the drugs comprised in this study were reported to the competent authorities on pharmacovigilance during the study time. The retrospective design of the study may have overlooked adverse reactions reported in clinical notes or underreporting of possible ADRs may have occurred, as the nonoccurrence or failure to identify ADRs may be explanations for this finding. ${ }^{10}$

We also observed that several drugs were given for each newborn, with a maximum number of 34 and 22 for preterm and full-term neonates, respectively. In fact, polypharmacotherapy is a common practice in NICUs (especially in high-risk neonates) and is associated with a statistically significant superior risk of developing ADRs; this risk is also associated with a greater use of unlicensed/ off-label medicines. ${ }^{32}$ There is lack of information on the compatibility of these drugs, particularly with regard to intravenous drug co-infusions; in fact, only $4 \%$ of intravenous co-infusions were shown to be compatible without restrictions in a $\mathrm{NICU}$, raising the risk of serious drug interactions. ${ }^{5}$

\section{Impact of European legislation}

Portugal follows the European Union Regulation On Medicinal Products for Paediatric Use (Regulation $n^{\circ}$ 1901/2006) implemented in 2007. ${ }^{36}$ After more than six years in force, EMA published a report on experience acquired with the application of this regulation which implemented a system of obligations, incentives and rewards to the development of drugs for paediatric age in European Member States. ${ }^{37}$ The document refers 600 Paediatric Investigation Plans agreed by the end of 2012, most of them for medicines that were not authorized in EU and the remaining related to new indications for patent-protected products or paediatric-use marketing authorizations. However, only $2 \%$ of these were exclusively addressed to neonatal intensive care. ${ }^{38}$

The number of paediatric clinical trials remained stable between 2006 and 2012 but there was an evident increase in the number of paediatric study participants, in particular for the age group of 0 to 23 months, who were normally not included in trials prior to 2008. Regarding to information on medicines used in children, more than 18000 study reports were submitted to EMA since 2008 , but it originated only 65 actual changes to authorized SPCs of products. ${ }^{38}$

These results are encouraging, but there is still a long process until we reach satisfactory and ideal paediatric pharmacological treatments.

\section{Limitations of this study}

The results reflect the reality of a single tertiary care unit, inserted in an academic hospital, so they may reflect only our local reality and not the current practice in centers throughout the country.

We did not assess the outcomes of medication use, so we cannot argue about the real risks versus benefits of their use.

\section{CONCLUSIONS}

Off-label prescription is a frequent practice in this Portuguese NICU, performed in $52.7 \%$ of the cases, mainly by the use of different doses and/or frequency from those stated in drugs' SPCs. These results give more strength to the need of update SPCs information in case of medicines whose use experience is long. Paediatric studies should be conducted on drugs intended to be introduced in the market too, with the aim of reducing the rate of off-label administrations in the future, providing safe and adequate medication to neonatal patients. Unlicensed drugs use was more modest $(4.4 \%)$, but reinforce the need for pharmaceutical companies to invest in new paediatric formulations. Great progresses have been made to reduce the inherent risks of these prescriptions, but it is crucial that paediatric and neonatal societies, government organizations and pharmaceutical companies join forces to achieve the approval of a larger number of innovative and beneficial medicines for in children.

\section{ACKNOWLEDGEMENTS}

We would like to thank Teresa Soares, from the Hospital Pharmacy, for clarifying the drugs trademarks used in our NICU.

\section{PROTECTION OF HUMANS AND ANIMALS}

The authors declare that the procedures were followed according to the regulations established by the Clinical Research and Ethics Committee and to the Helsinki Declaration of the World Medical Association.

\section{DATA CONFIDENTIALITY}

The authors declare having followed the protocols in use at their working center regarding patient's data publication. 


\section{CONFLICTS OF INTEREST}

The authors state no conflict of interests and have received no payment to perform this work.

\section{REFERENCES}

1. Lenk C. Off-label drug use in paediatrics: a world-wide problem. Curr Drug Targets. 2012;13:878-84.

2. Zingg W, Posfay-Barbe KM. Antibiotic use in children - off-label use Curr Drug Targets. 2012;13:885-92.

3. Lindell-Osuagwu L, Korhonen MJ, Saano S, Helin-Tanninen M, Naaranlahti T, Kokki H. Off-label and unlicensed drug prescribing in three paediatric wards in Finland and review of the international literature. J Clin Pharm Ther. 2009;34:277-87.

4. Ribeiro $M$, Jorge $A$, Macedo AF. Off-label drug prescribing in a Portuguese paediatric emergency unit. Int J Clin Pharm. 2013;35:30-6.

5. Fabiano V, Mameli C, Zuccotti GV. Adverse drug reactions in newborns, infants and toddlers: pediatric pharmacovigilance between present and future. Expert Opin Drug Saf. 2012;11:95-105

6. Cuzzolin L, Atzei A, Fanos V. Off-label and unlicensed prescribing for newborns and children in different settings: a review of the literature and a consideration about drug safety. Expert Opin Drug Saf. 2006;5:70318.

7. Palcevski G, Skocibusic N, Vlahovic-Palcevski V. Unlicensed and offlabel drug use in hospitalized children in Croatia: a cross-sectiona survey. Eur J Clin Pharmacol. 2012;68:1073-7.

8. Zhang L, Li Y, Liu Y, Zeng L, Hu D, Huang L, et al. Pediatric off-label drug use in China: risk factors and management strategies. J Evid Based Med. 2013;6:4-18.

9. Jacqz-Aigrain E. Drug policy in Europe Research and funding in neonates: current challenges, future perspectives, new opportunities. Early Hum Dev. 2011;87:S27-30.

10. Kimland E, Nydert P, Odlind V, Bottiger $Y$, Lindemalm S. Paediatric drug use with focus on off-label prescriptions at Swedish hospitals - a nationwide study. Acta Paediatr. 2012;101:772-8.

11. Pandolfini $C$, Bonati M. A literature review on off-label drug use in children. Eur J Pediatr. 2005;164:552-8.

12. Neubert A, Lukas K, Leis T, Dormann H, Brune K, Rascher W. Drug utilisation on a preterm and neonatal intensive care unit in Germany: a prospective, cohort-based analysis. Eur J Clin Pharmacol. 2010;66:8795.

13. Kumar P, Walker JK, Hurt KM, Bennett KM, Grosshans N, Fotis MA Medication use in the neonatal intensive care unit: current patterns and off-label use of parenteral medications. J Pediatr. 2008;152:412-5.

14. Carvalho CG, Ribeiro MR, Bonilha MM, Fernandes M Jr, Procianoy $\mathrm{RS}$, Silveira RC. Use of off-label and unlicensed drugs in the neonatal intensive care unit and its association with severity scores. J Pediatr. 2012:88:465-70.

15. Warrier I, Du W, Natarajan G, Salari V, Aranda J. Patterns of drug utilization in a neonatal intensive care unit. J Clin Pharmacol. 2006;46:449-55.

16. European Medicines Agency. Report on the survey of all paediatric uses of medicinal products in Europe [online]. 2010 [consulted $2013 \mathrm{Dec}$ 29]. Available from: http://www.ema.europa.eu/docs/en GB/document library/Report/2011/01/WC500101006.pdf

17. Anatomical Therapeutic Chemical Code - ATC/DDD Index 2013 [homepage]. WHO Collaborating Centre for Drug Statistics Methodology; 2013 [consulted 2013 Oct 30]. Available from: http://www.whocc.no/atc ddd index/.

18. Infomed - base de dados de medicamentos de uso humano [homepage] INFARMED - Autoridade Nacional do Medicamento e Produtos de Saúde IP; 2013. [consulted 2013 Oct 30]. Available from: http://www. infarmed.pt/infomed/pesquisa.php.

19. Nguyen KA, Claris $O$, Kassai $B$. Unlicensed and off-label drug use in a neonatal unit in France. Acta Paediatr. 2011;100:615-7.

20. Oguz SS, Kanmaz HG, Dilmen U. Off-label and unlicensed drug use in neonatal intensive care units in Turkey: the old-inn study. Int $\mathrm{J}$ Clin

\section{FUNDING SOURCES}

No subsidies or grants contributed to this work.

Pharm. 2012;34:136-41

21. Laforgia N, Nuccio MM, Schettini F, Dell'aera M, Gasbarro AR, Dell'erba $A$, et al. Off-label and unlicensed drug use among neonatal intensive care units (NICUs) in Southern Italy. Pediatr Int. 2014;56:57-9.

22. Lass J, Kaar R, Jogi K, Varendi H, Metsvaht T, Lutsar I. Drug utilisation pattern and off-label use of medicines in Estonian neonatal units. Eur $J$ Clin Pharmacol. 2011;67:1263-71.

23. Khdour MR, Hallak HO, Alayasa KS, AIShahed QN, Hawwa AF, McElnay JC. Extent and nature of unlicensed and off-label medicine use in hospitalised children in Palestine. Int J Clin Pharm. 2011;33:650-5.

24. Dell'Aera M, Gasbarro AR, Padovano M, Laforgia N, Capodiferro $D$, Solarino B, et al. Unlicensed and off-label use of medicines at a neonatology clinic in Italy. Pharm World Sci. 2007;29:361-7.

25. Dessi A, Salemi C, Fanos V, Cuzzolin L. Drug treatments in a neonata setting: focus on the off-label use in the first month of life. Pharm World Sci. 2010;32:120-4

26. Porta A, Esposito S, Menson E, Spyridis N, Tsolia M, Sharland M, et al. Off-label antibiotic use in children in three European countries. Eur J Clin Pharmacol. 2010;66:919-27.

27. Taketomo CK, Hodding JH, Kraus DM. Pediatric \& neonatal dosage handbook: a comprehensive resource for all clinicians treating pediatric and neonatal patients (pediatric dosage handbook). $19^{\text {th }}$ edition. Lexi Comp; 2012.

28. List of paediatric needs [homepage]. European Medicines Agency 2013 [consulted 2013 Oct 30]. Available from: http://www.ema.europa. eu/ema/index.jsp?curl=pages/regulation/document_listing/document listing_000096.jsp\&mid=WC0b01ac05800260a1.

29. Ferreira LA, Ibiapina CC, Machado MG, Fagundes ED. High prevalence of off-label and unlicensed drug prescribing in a Brazilian intensive care unit. Rev Assoc Med Bras. 2012;58:82-7.

30. Bensouda-Grimaldi L, Sarraf N, Doisy F, Jonville-Bera AP, Pivette J, Autret-Leca E. Prescription of drugs contraindicated in children: a national community survey. Eur J Clin Pharmacol. 2007;63:99-101.

31. INFARMED - Gabinete Jurídico e Contencioso. Legislação Farmacêutica Compilada - Despacho n. ${ }^{\circ}$ 18694/2010 [online]. 2010 [consulted 2013 Dec 29]. Available from: http://www.infarmed.pt/portal/page/portal/ INFARMED/legislacao/legislacao farmaceutica_compilada/titulo iii/ titulo_iii_capitulo_ii/067-A01_Desp_18694_2010doc.pdf.

32. Conroy S, McIntyre J. The use of unlicensed and off-label medicines in the neonate. Semin Fetal Neonatal Med. 2005;10:115-22.

33. Conroy S. Association between licence status and medication errors Arch Dis Child. 2011:96:305-6.

34. INFARMED - Autoridade Nacional do Medicamento e Produtos de Saúde IP. Circular Informativa N. ${ }^{\circ} 184 / C D$ - Utilização de medicamentos off-label [online]. 2010 [consulted 2013 Sep 29]. Available from: http:// www.infarmed.pt/portal/pls/portal/docs/1/8668342.PDF.

35. Direção Geral de Saúde. Norma 015/2013 - Consentimento informado, esclarecido e livre para atos terapêuticos ou diagnósticos e para a participação em estudos de investigação [online]. 2013 [consulted 2013 Dec 19]. Available from: http://www.dgs.pt/directrizes-da-dgs/normas-ecirculares-normativas/norma-n-0152013-de-03102013.aspx.

36. European Parliament and the Council of the European Union. Regulation (EC) No 1901/2006 [online]. 2006 [consulted 2013 Dec 29]. Available from: http://ec.europa.eu/health/files/eudralex/vol-1/reg_2006_1901/ reg_2006_1901_en.pdf.

37. Rocchi F, Paolucci P, Ceci A, Rossi P. The European paediatric legislation: benefits and perspectives. Ital J Pediatr. 2010;36:56.

38. European Comission. Better medicines for children: from concept to reality [online]. 2013 [consulted 2013 Dec 29]. Available from: http:// ec.europa.eu/health/files/paediatrics/2013_com443/paediatric_reportcom(2013)443 en.pdf. 


\section{Joana SILVA, Filipa FLOR-DE-LIMA, Henrique SOARES, Hercília GUIMARÃES \\ Off-Label and Unlicensed Drug Use in Neonatology: Reality in a Portuguese University Hospital}

Acta Med Port 2015:28:297-306

Publicado pela Acta Médica Portuguesa, a Revista Científica da Ordem dos Médicos

Av. Almirante Gago Coutinho, 151

1749-084 Lisboa, Portugal.

Tel: +351218428215

E-mail: submissao@actamedicaportuguesa.com

www.actamedicaportuguesa.com

ISSN:0870-399X | e-ISSN: 1646-0758

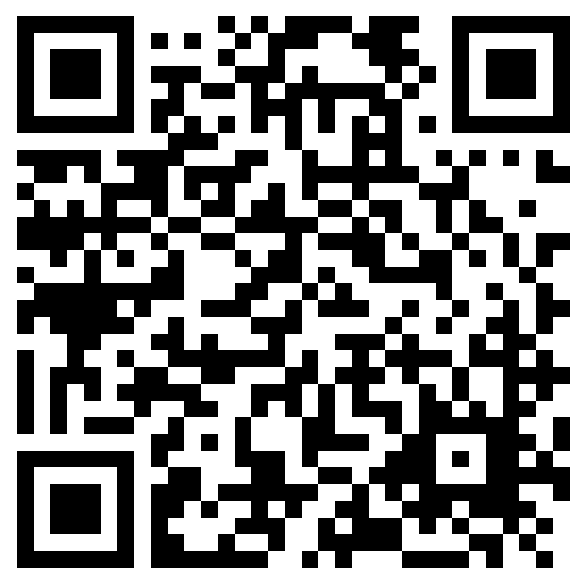

